\title{
Riparian vegetation subsidizes sea lamprey ammocoetes in a nursery area
}

\author{
${\text { Ester } \operatorname{Dias}^{1}(\mathbb{D} \cdot \text { Maria L. Miranda }}^{2} \cdot$ Ronaldo Sousa $^{2} \cdot$ Carlos Antunes $^{1,3}$
}

Received: 25 July 2018 / Accepted: 10 April 2019

(c) Springer Nature Switzerland AG 2019

\begin{abstract}
Fluxes of organic matter $(\mathrm{OM})$ from terrestrial ecosystems subsidize stream food webs, which support the production of ecologically and economically important species such as the sea lamprey Petromyzon marinus. Debris have been previously observed in the gut contents of sea lamprey ammocoetes, but their origin and/or the nutritional sources assimilated are still poorly known. We used carbon $\left(\delta^{13} \mathrm{C}:{ }^{13} \mathrm{C} /{ }^{12} \mathrm{C}\right)$ and nitrogen $\left(\delta^{15} \mathrm{~N}:{ }^{15} \mathrm{~N} /{ }^{14} \mathrm{~N}\right)$ stable isotopes to identify the main OM sources supporting the production of ammocoetes in a tributary of the Minho River (NW-Iberian Peninsula). Ammocoetes $\delta^{13} \mathrm{C}$ and $\mathrm{C}: \mathrm{N}$ values increased with length. Smaller individuals likely assimilated more ${ }^{13} \mathrm{C}$ - depleted sources such as fresh or decaying plant material. The increase in the $\mathrm{C}: \mathrm{N}$ values with length suggests that ammocoetes accumulate lipids to support their metamorphosis and recruitment into an adult animal. Ammocoetes smaller than $30 \mathrm{~mm}$ presented an unusual variability for both $\delta^{15} \mathrm{~N}$ and $\delta^{13} \mathrm{C}$ values, with values varying between $3.2 \%$ and $17.8 \%$ for $\delta^{15} \mathrm{~N}$ and between $-38 \%$ and $-25.5 \%$ o for $\delta^{13} \mathrm{C}$ in the same sampling site. This suggests that factors such as organic pollution inputs or time to the first feeding may have contributed to the observed variability. Detritus from the adjacent riparian vegetation was identified as the main food source assimilated by sea lamprey ammocoetes. The stable isotope mixing model (95\% CI) indicates that the relative contribution of decaying riparian plants detritus varied between $38-59 \%$ and $55-73 \%$ at the end of the summer decreasing towards the end of the winter (2-34\%). The relative contribution of other terrestrial-derived OM (i.e. fresh riparian detritus and particulate OM with terrestrial origin) was only relevant ( $>40 \%)$ at the end of the winter. This study shows that there is a strong connectivity between the stream food web and the adjacent riparian ecosystem, and that protection of both riparian and catchment forest cover are essential to preserve terrestrial-aquatic linkages which can support the development of sea lamprey ammocoetes.
\end{abstract}

Keywords Petromyzon marinus $\cdot$ Stable isotopes $\cdot$ Spatial subsidies $\cdot$ Allochthonous organic matter

Ester Dias and Maria L. Miranda made equal contributions to this work.

Ester Dias

esterdias@ ciimar.up.pt

1 CIMAR/CIIMAR-Interdisciplinary Centre of Marine and Environmental Research, University of Porto, Terminal de Cruzeiros do Porto de Leixões s/n, Av. General Norton de Matos, 4450-208 Matosinhos, Portugal

2 CBMA-Centre of Molecular and Environmental Biology, Department of Biology, University of Minho, Campos de Gualtar, 4710-057 Braga, Portugal

3 Aquamuseu do Rio Minho, Parque do Castelinho s/n, 4920-290 Vila Nova de Cerveira, Portugal

\section{Introduction}

Streams and the adjacent terrestrial ecosystems are linked by resource flow across their boundaries, which includes exchange of organic and inorganic materials such as nutrients, leaves, wood debris, and also invertebrates and fish (Baxter et al. 2005; Richardson et al. 2010). Stream detritivores feed on decaying leaf litter and wood debris from riparian areas, either by consuming epixylon or digesting plant material with the help of microbial symbionts (Richardson et al. 2010). Although the bioenergetic consequences of feeding on terrestrial detritus are still poorly known, detritivores productivity can decrease in the absence of litter inputs producing bottom-up effects on streams food webs (Wallace et al. 1999). These food webs can also benefit from seasonal resources pulses deriving from fish migrations. For 
example, the post-spawned carcasses of the Pacific salmon (Oncorhynchus spp.) can increase dissolved nutrients, biofilm, macroinvertebrate production, and fish growth rates (Janetski et al. 2009; Rex and Petticrew 2008; Collins et al. 2016; Weaver et al. 2016). They can also subsidize terrestrial ecosystems when moved by terrestrial carnivores and incorporated by terrestrial plants and invertebrates (e.g. Gende et al. 2002; Hocking and Reynolds 2011).

Streams food webs support the production of several species of economic and ecological interest such as the anadromous sea lamprey, Petromyzon marinus (Linnaeus 1758). Ammocoetes (i.e. larvae) of this species spend from 3 to 7 years in freshwater habitats, living burrowed in fine sediments, protected from possible predators (Dawson et al. 2015). After several years in freshwater habitats, they undergo metamorphosis which allows young post-metamorphic lampreys to migrate to the sea and begin hematophagous feeding (Youson 1980). Metamorphosis is a synchronized event during which lampreys spend between 4 and 10 months without feeding (Potter 1980; Youson 1980). The long fasting period implies that this is a critical stage in the life cycle (Swink 2003), and therefore ammocoetes have to obtain enough energy reserves to survive this period.

Ammocoetes occupy a relatively low trophic position in stream food webs as deposit-feeding detritivores, feeding on algae (primarily diatoms), organic detritus, and bacteria (Sutton and Bowen 1994; Quintella 2000). Stomach content analysis also reported the presence of protozoans, nematodes, and rotifers (Beamish 1980). Although materials they ingest have been documented, the origin of the organic matter $(\mathrm{OM})$ sources that support ammocoetes as they develop are still poorly known. Carbon $\left({ }^{13} \mathrm{C}:{ }^{13} \mathrm{C} /{ }^{12} \mathrm{C}\right)$ and nitrogen $\left(\delta^{15} \mathrm{~N}:{ }^{15} \mathrm{~N} /{ }^{14} \mathrm{~N}\right)$ stable isotopes offer an alternative approach to gut content analysis to determine the origin of nutritional sources. For consumers, the stable isotope composition of tissues is a time-integrated signal of the food sources in the ecosystem that were incorporated into an organism's structural components and energy reserves (Peterson and Fry 1987). Thus, the stable isotope ratio of a consumer reflects its diet, demonstrating an average trophic fractionation (i.e., the difference between the consumer and its diet) of ca. $0.4 \% \circ \delta^{13} \mathrm{C}$ and $3.4 \% \circ \delta^{15} \mathrm{~N}$ per trophic level (Post 2002), although with variation around these averages (Caut et al. 2009). Stable isotopes can also help to discriminate between assimilated sources with different origins. For instance, the $\delta^{13} \mathrm{C}$ and $\delta^{15} \mathrm{~N}$ values of upland plants, marsh vegetation, and phytoplankton differ with respect to $\mathrm{C}$ and $\mathrm{N}$ source and pathway of C fixation (Goericke et al. 1994; Lajtha and Marshall 1994). Riparian plants using the C3 pathway have a $\delta^{13} \mathrm{C}$ of about $-28 \%$ o because there is an uptake fractionation of about $-21 \%$ over atmospheric $\mathrm{CO}_{2}\left(\delta^{13} \mathrm{C}-7 \%\right.$ o $)$ (Smith and Epstein 1971). In contrast, $\mathrm{C} 4$ plants are more ${ }^{13} \mathrm{C}$ - enriched $\left(\delta^{13} \mathrm{C}:-13 \%\right.$ ) owing to reduced fractionation
(Smith and Epstein 1970; Fry and Sherr 1984). In freshwater ecosystems where the DIC $\delta^{13} \mathrm{C}$ is highly depleted $(<-10 \%$ ), phytoplankton may also be distinguished from riparian vegetation (Hoffman and Bronk 2006). Microphytobenthos (MPB) are more ${ }^{13} \mathrm{C}$-enriched than phytoplankton due to the existence of a diffusive boundary layer at the sediment-water interface that reduces isotopic fractionation (France 1995). The N stable isotope composition can also help to distinguish between ${ }^{15} \mathrm{~N}$-depleted terrestrial OM $\left(\delta^{15} \mathrm{~N}:-4\right.$ to $\left.4 \% o\right)$ and ${ }^{15} \mathrm{~N}$-enriched aquatic OM sources $\left(\delta^{15} \mathrm{~N}: 6-10 \%\right.$ ) (Peterson and Fry 1987; Cloern et al. 2002).

Prior work with stable isotopes on sea lamprey ammocoetes provided important insights into their feeding ecology. For example, studies conducted in the Laurentian Great Lakes (North America) found that ammocoetes rely on both aquatic primary production (i.e., autochthonous $\mathrm{OM}$ ) and terrestrial plant material (i.e., allochthonous OM) (Evans and Limburg 2015; Evans and Bauer 2016a). Also, Weaver et al. (2018) suggested that ammocoetes can assimilate nutrients from post-spawned lamprey carcasses. These findings strength the importance of maintaining ecosystem connectivity to promote the growth and survival of this species. Thus, the aim of this study was to identify the origin of the OM sources assimilated by sea lamprey ammocoetes in a nursery area and quantify its importance to their biomass. This study was conducted in a tributary of the Minho River, Veiga da Mira River (NW-Iberian Peninsula, SW-Europe), where sea lamprey is economically and culturally important (Araújo et al. 2016). Because sea lamprey ammocoetes are less mobile during this stage, we hypothesize that they would derive their energy essentially from autochthonous OM. However, because terrestrially-derived OM is abundant in streams and rivers (Cole et al. 2011) we expect allochthonous OM to also contribute to their biomass. To test our hypothesis, we identified the potential OM sources to sea lamprey ammocoetes using $\mathrm{C}$ and $\mathrm{N}$ stable isotopes at the end of low and high river discharge periods. We chose these scenarios because in an earlier study (Dias et al. 2016) it was shown that river discharge plays an important role in the distribution and availability of allochthonous OM in the Minho River.

\section{Materials and methods}

\section{Study area}

The Minho River is located in the NW-Iberian Peninsula (SW Europe; Fig. 1) and has an extension of about $300 \mathrm{~km}$. The last $70 \mathrm{~km}$ serve as northwestern border between Portugal and Spain (Antunes et al. 2011). The tidal influence extends until $40 \mathrm{~km}$ upstream; however, the salinity intrusion only goes up to $25 \mathrm{~km}$, comprising 


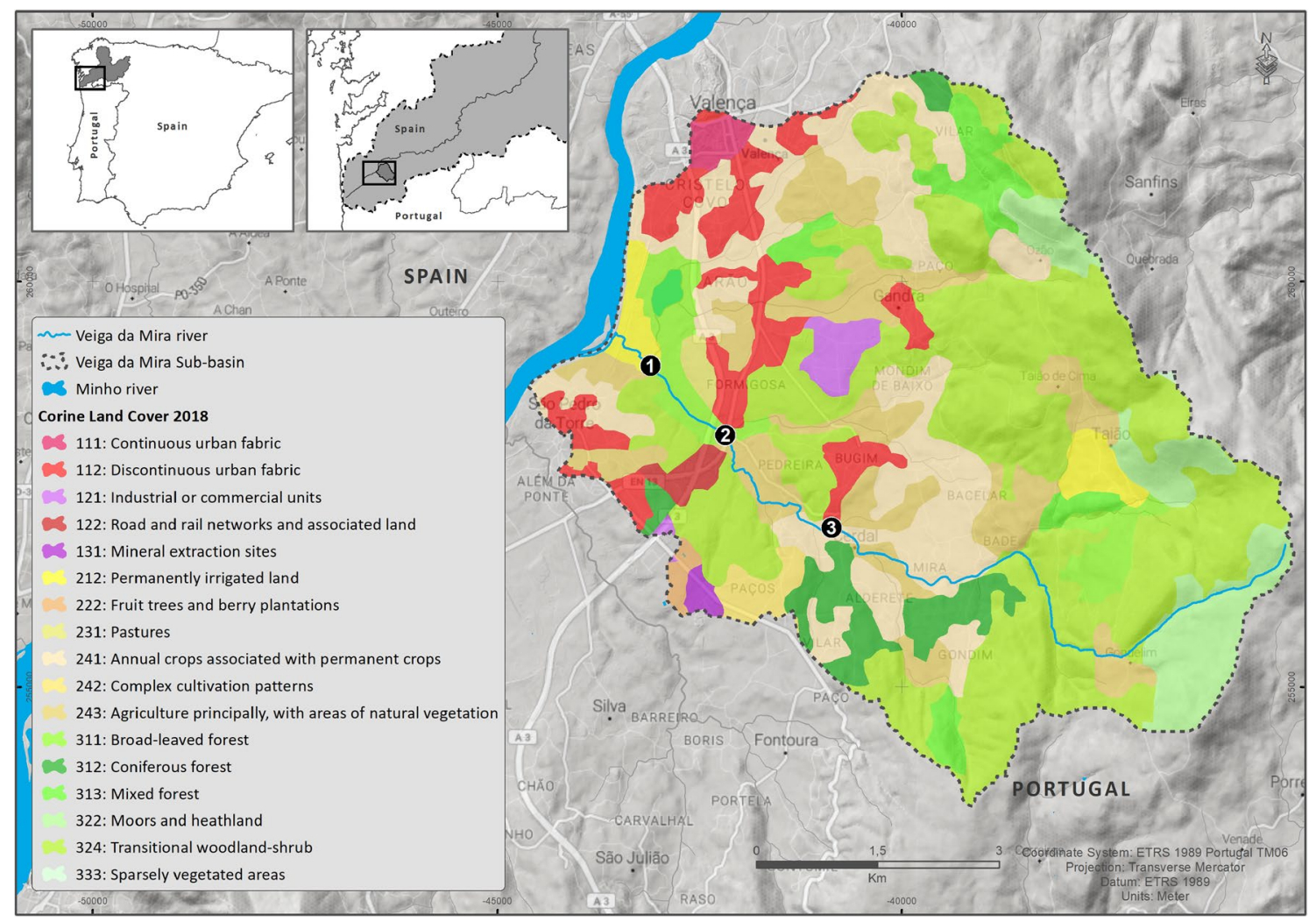

Fig. 1 Location of the sampling sites along the Veiga da Mira River (NW- Iberian Peninsula). Details about the land use of the basin are also shown

the estuarine area about $23 \mathrm{~km}^{2}$ (Sousa et al. 2008). River flow varies seasonally: the maximum flow $\left(2500 \mathrm{~m}^{3} \mathrm{~s}^{-1}\right)$ is associated with periods of intense precipitation in the winter/early spring, and the minimum flow $\left(60 \mathrm{~m}^{3} \mathrm{~s}^{-1}\right)$ occurs in the summer/early autumn, associated with periods of drought (Antunes et al. 2011). The international section of the Minho River is a Natura 2000 site due to its ecological importance (EIONET 2018). In this area it is possible to find natural habitats of Community Importance designated as Special Zones of Conservation such as alluvial forests with Alnus glutinosa and Fraxinus excelsior (ICNF 2018).

The sampling occurred at Veiga da Mira River, which has a total length of $12.6 \mathrm{~km}$ and a catchment area of $46.5 \mathrm{~km}^{2}$. Its watershed has a mixed land usage: ca. $60 \%$ is forest or natural grasslands, $30 \%$ agricultural activities, and 10\% urban and industrial activities (Fig. 1). Along with Coura River, Veiga da Mira River is known to be a preferential site for sea lamprey reproduction and spawning and therefore usually presents high densities of sea lamprey larvae (Antunes et al. 2011; Sousa et al. 2012).

\section{Field sampling}

Sampling was conducted in three sites along the Veiga da Mira River (Fig. 1), which presented ca. 2-3 m wide and up to $0.5 \mathrm{~m}$ depth. Samples were collected during a 2 week period in September 2014 (hereafter, end of summer) and March 2015 (hereafter, end of winter), to characterize low and high river discharge conditions, respectively (Confederación Hidrográfica del Miño-Sil; Fig. 2).

The organic matter (OM) sources sampled were selected based on the feeding mode of sea lamprey ammocoetes (Sutton and Bowen 1994; Evans and Limburg 2015): particulate OM (POM), sediment OM (SOM), microphytobenthos (MPB), aquatic and terrestrial vegetation, and plant detritus.

At each site, $10 \mathrm{~L}$ of surface water samples were collected into a sterile carboy and kept refrigerated until processing at the laboratory. Because the three sampling sites are very shallow (i.e. less than $1 \mathrm{~m}$ ), we assumed that there was no water stratification. From these samples, we determined the chlorophyll $a(\mathrm{Chl} a)$ concentration $\left(\mu \mathrm{g} \mathrm{L}^{-1}\right)$, and POM isotopic composition (including particulate organic 


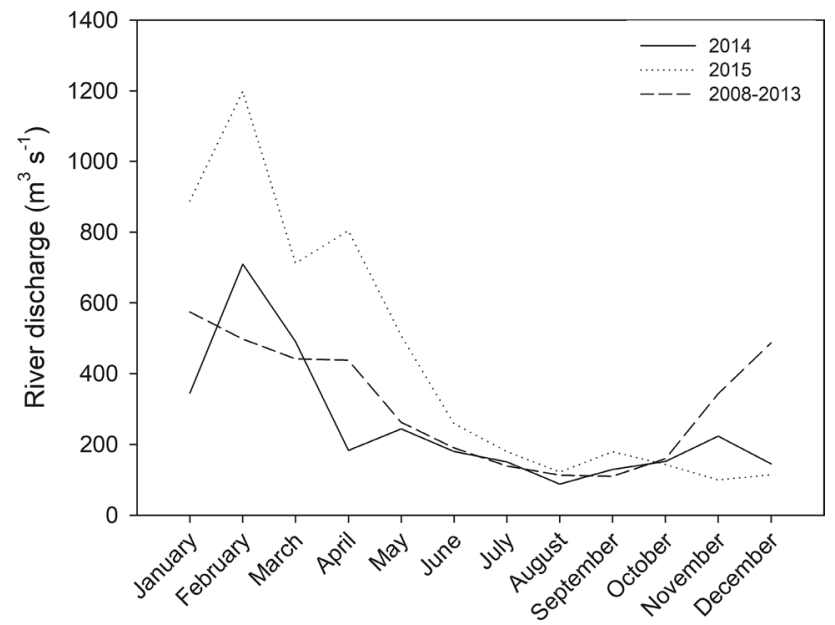

Fig. 2 Average Minho River discharge measured between 2008 and 2013 (dashed line) and in 2014 (solid line) and 2015 (dotted line) (gauge located at Salvaterra-Confederación Hidrográfica del MiñoSil; 2018)

carbon [POC] $\delta^{13} \mathrm{C}$, particulate nitrogen [PN] $\delta^{15} \mathrm{~N}$, and molar C:N). The POM and Chl $a$ water samples were prefiltered with $200 \mu \mathrm{m}$ sieves. Water was filtered onto precombusted $\left(500{ }^{\circ} \mathrm{C}\right.$ for $2 \mathrm{~h}$ ) Whatman GF/F filters and kept frozen $\left(-20^{\circ} \mathrm{C}\right)$ until analysis.

Sediments, aquatic and terrestrial vegetation, and detrital foliage were hand collected using gloves. Sediments were collected at the center of the stream, by excavating to a depth of ca. $20 \mathrm{~cm}$. The dominant aquatic plants (not identified) were handpicked both at the center of the stream and closer to the margins, when present. The dominant terrestrial plants (i.e. Alnus sp., Fraxinus sp., and Salix sp) and its detritus were collected from the stream margins. At least, three replicates were collected from each source (or species, when applicable) per station in each sampling period. Samples were refrigerated in the field. After returning to the laboratory, samples were kept frozen at $-20{ }^{\circ} \mathrm{C}$ until processing.

A total of 180 sea lamprey ammocoetes were collected by electrofishing using an electrofisher backpack (continuous current [DC], 200-400 V; 1-3 A; Electracatch International, Dublin, Ireland). Electrofishing was conducted, in delimited areas of $1 \mathrm{~m}^{2}$, by a series of successive shocks until no more ammocoetes were captured. Upon emergence from the sediment, ammocoetes were collected in $1 \mathrm{~mm}$ mesh size nets and kept alive with aeration during transportation. In the laboratory, organisms were measured and then kept frozen at $-20{ }^{\circ} \mathrm{C}$ until processing.

Water parameters, including temperature, conductivity, and $\mathrm{pH}$ were measured with an YSI 6600V2 multiparametric probe (YSI; Yellow Springs, OH, EUA). Sea lamprey ammocoetes are considered sedentary burrowing animals, and the selection of sediment characteristics to burrow appears to be size-dependent (Almeida et al. 2002). Thus, sediment samples were also collected in order to estimate de particle size composition of the substrate where the larvae were buried in and to determine the OM proportion available in the sediment.

\section{Laboratory analyses}

Water samples for Chl $a$ analysis were filtered through $0.7 \mu \mathrm{m}$ pore filters (Whatman GF/F), without exceeding $100 \mathrm{~mm} \mathrm{Hg}$ of filtration pressure (Lorenzen 1967) and filters were placed in glass vials with $90 \%$ acetone for $24 \mathrm{~h}$ in the dark to elute the pigments. After that period, filters were discarded and the samples were processed as in Lorenzen (1967) and analyzed on a Spectronic 20 Genesys spectrophotometer. Chl $a$ concentration was calculated following Lorenzen (1967).

For granulometry analyses, sediment samples were put into a furnace for $72 \mathrm{~h}$ at $60{ }^{\circ} \mathrm{C}$ following Sousa et al. (2007). In summary, a dimensional analysis was performed by sifting with a Ro-Tap agitator, with columns of sieve, according to the dimensional scale of different mesh sizes (corresponding: $>2 \mathrm{~mm}$-gravel; 1-2 $\mathrm{mm}$ : coarse sand; 0.5-1 $\mathrm{mm}$ : coarse sand; $0.25-0.5 \mathrm{~mm}$ : medium sand; $0.125-0.25 \mathrm{~mm}$ : fine sand; 0.063-0.125 mm: very fine sand; $<0.063 \mathrm{~mm}$ : silt and clay) and the percentage of each class was expressed as $\%$ of total weight. Organic matter contained in the sediment was determined, after combusting during $24 \mathrm{~h}$ at $550{ }^{\circ} \mathrm{C}$ in a muffle furnace (Sousa et al. 2007). Values were expressed as percent weight loss on ignition.

Filters for POM analysis were cut in half and were fumed with concentrated $\mathrm{HCl}$ to remove inorganic carbonates and determine $\delta^{13} \mathrm{C}_{\mathrm{POC}}$. Afterwards they were dried at $60^{\circ} \mathrm{C}$ for $24 \mathrm{~h}$ (Lorrain et al. 2003). The half used to determine $\delta^{15} \mathrm{~N}_{\mathrm{PN}}$ was only dried in the same conditions as above.

Sediment samples were ground and a subsample for $\delta^{13} \mathrm{C}_{\mathrm{SOC}}$ was rinsed with $10 \% \mathrm{HCl}$ to remove carbonates, and dried at $60{ }^{\circ} \mathrm{C}$ for $48 \mathrm{~h}$. Plants and detritus were cleaned with deionized water, and dried at $60{ }^{\circ} \mathrm{C}$. Sediments, plants, and plant detritus were ground to a fine powder with a mixer mill for stable isotope analysis.

Muscle tissue from each sea lamprey ammocoete was removed. From smaller individuals (lower than $40 \mathrm{~mm}$ ) the gut was removed, and the entire animal was used. Subsequently samples were dried in an oven at $60{ }^{\circ} \mathrm{C}$ and ground into powder with a mortar and pestle.

Stable isotopes ratios were measured using a Thermo Scientific Delta V Advantage Isotope Ratio Mass Spectrometer (IRMS) via Conflo IV Interface (MARINNOVA, University of Porto). Stable isotope ratios were reported in $\delta$ notation with Pee Dee Belemnite and air as standards for $\delta^{13} \mathrm{C}$ and $\delta^{15} \mathrm{~N}$, respectively. The analytical error, the average SD of replicate reference material, was $\pm 0.1 \%$ for $\delta^{13} \mathrm{C}$ and $\delta^{15} \mathrm{~N}$. 


\section{Data analyses}

To test for possible differences in the $\delta^{13} \mathrm{C}$ and $\delta^{15} \mathrm{~N}$ values between sampling sites and seasons, we performed a two-way PERMANOVA (type-III) in a crossed design using Euclidean similarity distance, with sites (three levels: 1, 2, and 3 ) and seasons (two levels: end of summer and end of winter) as fixed factors. PERMANOVA tests the simultaneous response of one or more variables to one or more factors in an ANOVA experimental design on the basis of any distance measure, using permutation methods (Anderson et al. 2008). In all PERMANOVA tests, the statistical significance of variance $(\alpha=0.05)$ was tested using 9999 permutations of residuals within a reduced model. When the number of permutations was lower than 150, the Monte Carlo $\mathrm{p}$ value was considered. Statistical tests were conducted using PRIMER v.6.1.11 ${ }^{\circledR}$ (Clarke and Gorley 2006) with PERMANOVA+1.0.1 (Anderson et al. 2008).

The contribution of the different OM sources to sea lamprey larvae biomass was quantified by a dual-stable isotope mixing model, which uses Bayesian inference to solve the indeterminate equations (more than $n+1$ sources relative to $\mathrm{n}$ stable isotopes), producing a probability distribution that represents the likelihood a given source contributes to the consumer biomass (Parnell et al. 2010). We used the SIAR package (Stable Isotope Analysis in R; Parnell et al. 2010), which is part of the open source statistical language R (R Development Core Team 2018). The model allows each of the sources and the trophic enrichment factor (TEF; or trophic fractionation) to be assigned as a normal distribution, rather than a single datum (Parnell et al. 2010). SIAR will produce a range of feasible solutions to the mixing problem to which are assigned credibility intervals (CIs), analogous to the confidence intervals used in frequentist statistics (in this study, 95\% CI; Parnell et al. 2010). SIAR also includes a residual error term.

For each site sampled, we identified the OM sources supporting ammocoetes production using graphical analysis, by comparing their $\delta^{13} \mathrm{C}$ and $\delta^{15} \mathrm{~N}$ values to $\mathrm{OM}$ source $\delta^{13} \mathrm{C}$ and $\delta^{15} \mathrm{~N}$ values, after adjusting for one trophic level. As no $P$. marinus specific TEF values are available, to the best of our knowledge, we used the TEF estimates from Post (2002): $+0.4 \pm 1.3 \% \circ \delta^{13} \mathrm{C},+3.4 \pm 1.0 \%$ o $\delta^{15} \mathrm{~N}$. The $\delta^{13} \mathrm{C}$ and $\delta^{15} \mathrm{~N}$ values from MPB were retrieved from the literature from freshwater areas in the nearby Minho River (Dias et al. 2016).

The sea lamprey ammocoetes $\delta^{13} \mathrm{C}$ values were not corrected for lipid content. Lipids are depleted in ${ }^{13} \mathrm{C}$ when compared to protein and carbohydrates which usually results in an inverse relationship between $\mathrm{C}: \mathrm{N}$ and $\delta^{13} \mathrm{C}$ in muscle tissues for a range of aquatic animals (DeNiro and Epstein 1977). However, previous studies on lamprey ammocoetes showed that their $\mathrm{C}: \mathrm{N}$ values are positively correlated with $\delta^{13} \mathrm{C}$ values (Evans and Bauer 2016a, b), likely because ammocoetes produce greater relative amounts of biosynthesized intramuscular ${ }^{13} \mathrm{C}$ - enriched lipids (Stott et al. 1997), or selective assimilate ${ }^{13} \mathrm{C}$ - enriched lipid compounds from their food sources (Canuel et al. 1997), or both.

\section{Results}

\section{General abiotic and biotic characterization}

Water temperature, the percentage of fine sediments $(<63 \mu \mathrm{m})$, and the organic matter content in the sediments were the main factors differentiating sampling sites between seasons. Water temperature was higher at the end of the summer than at the end of the winter, while the percentage of fine sediments and the organic matter content in the sediments were overall higher at the end of the winter (Table 1). The relative percentage of fine sediments was higher in station 1 at the end of the winter, being ten times higher than in the other sites, while the opposite was observed at the end of the summer (Table 1). The organic matter content in the sediments was low $(<1 \%)$ and similar between sites at the end of the summer, while at the end of the winter was up to twenty times higher than at the end of the summer (Table 1).
Table 1 Environmental data obtained at each sampling site $(1,2,3)$ at the end of the summer 2014 (S) and winter 2015 (W), including water temperature $\left({ }^{\circ} \mathrm{C}\right)$, conductivity $(\mathrm{ms} / \mathrm{cm}), \mathrm{pH}$, and $\mathrm{Chl} a$ $\left(\mu \mathrm{g} \mathrm{L}^{-1}\right)$

\begin{tabular}{llllllll}
\hline Station & $\begin{array}{l}\text { Water } \\
\text { temperature } \\
\left({ }^{\circ} \mathrm{C}\right)\end{array}$ & $\begin{array}{l}\text { Conductiv- } \\
\text { ity }(\mathrm{ms} / \mathrm{cm})\end{array}$ & $\mathrm{pH}$ & $\begin{array}{l}\text { Fine sedi- } \\
\text { ments }(\%)\end{array}$ & $\begin{array}{l}\text { Organic matter in } \\
\text { sediments }(\%)\end{array}$ & $\mathrm{Chl} a\left(\mu \mathrm{L} \mathrm{L}^{-1}\right)$ & $\begin{array}{l}\text { Abundance } \\
\left(\text { ind m }^{-2}\right)\end{array}$ \\
\hline $1 \mathrm{~S}$ & 18.5 & 0.08 & 6.2 & 0.4 & 0.6 & 0.2 & 10.7 \\
$2 \mathrm{~S}$ & 17.2 & 0.07 & 7 & 0.1 & 0.5 & 0.1 & 0.1 \\
$3 \mathrm{~S}$ & - & - & - & 0.9 & 0.7 & 0.3 & 46.5 \\
$1 \mathrm{~W}$ & 11.2 & 0.06 & 7 & 10.1 & 20 & - & 64 \\
$2 \mathrm{~W}$ & 11.7 & 0.06 & 7 & 0.7 & 20 & 0.1 & 20 \\
$3 \mathrm{~W}$ & 11.4 & 0.04 & 7 & 0.3 & 8 & - & 13 \\
\hline
\end{tabular}

Sediment data include the proportion of fine sediments (\%), and the organic matter content (\%). Data about the number of ammocoetes collected by $\mathrm{m}^{2}$ were also included. Where no value is shown, data were not collected 


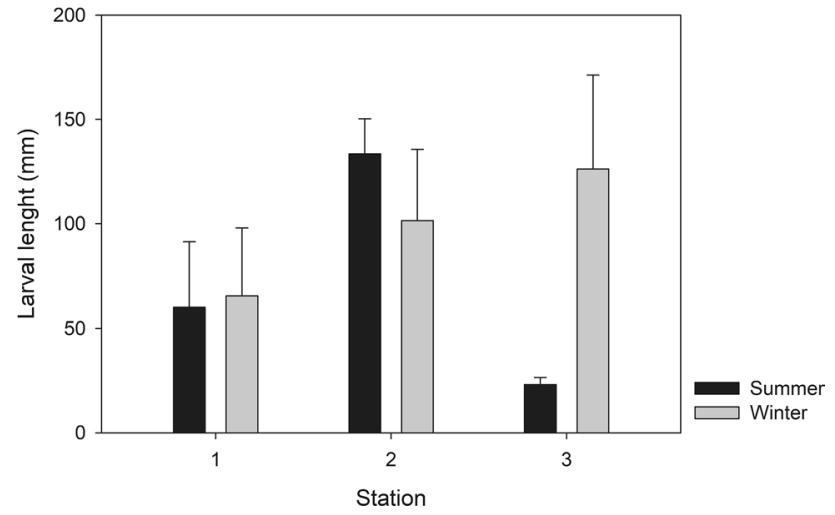

Fig. 3 Average length $(\mathrm{mm})$ of the ammocoetes collected in sites 1 , 2 , and 3 at the end of the summer 2014 (black) and at the end of the winter 2015 (gray). Standard deviation is represented by the black lines

Table 2 Results from PERMANOVA test for differences in ammocoetes $\delta^{13} \mathrm{C}$ and $\delta^{15} \mathrm{~N}$ values between sites (sites 1, 2, and 3) in each season (A) and between seasons in each site (B)

(A)

\begin{tabular}{lrrrrrr}
\hline & $t$ & $p$ value & & $t$ & $p$ value \\
\cline { 1 - 3 } \cline { 5 - 6 } Summer & & & Site 1 & & \\
St 1 vs St 2 & 1.14 & 0.30 & S vs W & 2.07 & 0.03 \\
St 1 vs St 3 & 6.13 & $<0.01$ & Site 2 & & \\
St 2 vs St 3 & 5.21 & $<0.01$ & S vs W & 1.32 & 0.19 \\
Winter & & & Site 3 & & \\
St 1 vs St 2 & 2.78 & $<0.01$ & S vs W & 6.12 & $<0.01$ \\
St 1 vs St 3 & 1.89 & 0.04 & & & \\
St 2 vs St 3 & 0.18 & 0.97 & & & \\
\hline
\end{tabular}

Density of ammocoetes was higher at the end of the winter in site 1 (64 ind $\mathrm{m}^{-2}$; Table 1$)$, while the lowest value was registered in site 2 at the end of the summer $\left(0.1\right.$ ind $\mathrm{m}^{-2}$; Table 1). The length of the ammocoetes varied between stations. The smallest larvae were collected in site 3 at the end of the summer with an average $( \pm$ SD) value of $23 \pm 3 \mathrm{~mm}$ (Fig. 3) while the largest larvae were collected in site 2 at the end of the summer with an average $( \pm$ SD) value of $134 \pm 17 \mathrm{~mm}$ (Fig. 3).

\section{Stable isotopes and C:N ratios of ammocoetes tissue}

There were significant differences in the $\delta^{13} \mathrm{C}$ and $\delta^{15} \mathrm{~N}$ values between the interaction sites $\times$ season (Pseudo- $F=25.71$; $P<0.01)$. Pairwise comparisons showed significant differences in the isotope ratios between sites (Table $2 \mathrm{a}$ ) and for each site between seasons (Table $2 b$ ). There were significant differences between the $\delta^{13} \mathrm{C}$ and $\delta^{15} \mathrm{~N}$ values from ammocoetes collected in site 3 , at the end of the summer, and those collected at sites 1 and 2 (Table 2a). Ammocoetes collected in site 3 presented the lowest average $( \pm \mathrm{SD}) \delta^{13} \mathrm{C}$ values $\left(-32.1 \pm 3.1 \%\right.$ ) and the highest $\delta^{15} \mathrm{~N}$ average $( \pm \mathrm{SD})$ values $(11.8 \pm 3.7 \%$ ) , and also a high variability in both stable isotopes with $\delta^{13} \mathrm{C}$ values varying between $-37.9 \%$ o and $-25.5 \%$ (Fig. 4b) and $\delta^{15} \mathrm{~N}$ values varying between 3.1 and $17.8 \%$ (Fig. 4c). At the end of the winter, only ammocoetes collected at sites 1 and 2 were significantly different (Table 2a). There were no significant differences in the ammocoetes $\delta^{13} \mathrm{C}$ and $\delta^{15} \mathrm{~N}$ values between seasons, with the exception of site 3 (Table $2 \mathrm{~b}$ ), where the ammocoetes collected at the end of the summer were more ${ }^{13} \mathrm{C}$ - depleted and ${ }^{15} \mathrm{~N}$-enriched than those collected at the end of the winter (Fig. 4b, c, e, f).

Overall, there was an increase in the $\delta^{13} \mathrm{C}$ values and a decrease in the $\delta^{15} \mathrm{~N}$ values with increasing length (Fig. 4b, c, e, f) at the end of the summer (Fig. 4b, c) and at the end of the winter (Fig. 4e, f). The average ( \pm SD) $C: N$ values also increased with ammocoetes length (Fig. 4 a, d) varying between $4.6 \pm 0.9$ (site 3 ) and $5.7 \pm 0.9$ (site 2 ) at the end of the summer (Fig. 4a) and between 10.4 \pm 3.3 (site 3) and $5.0 \pm 1.3$ (site 1) (Fig. 4d). In general, ammocoetes' $\delta^{13} \mathrm{C}$ values increased with $\mathrm{C}: \mathrm{N}$ values (Fig. 5).

\section{Ammocoetes food sources}

Overall, sea lamprey ammocoetes stable isotope ratios were intermediate between the OM sources measured, after adjusting for trophic fractionation, indicating reliance on multiple OM sources (Fig. 6). During summer, in sites 1 and 2 , the stable isotope ratios of ammocoetes indicate they assimilated ${ }^{15} \mathrm{~N}$ - depleted and ${ }^{13} \mathrm{C}$ - enriched sources, which suggests that detritus and MPB were likely sources of OM (Fig. 6). In site 3 , the ammocoetes $\delta^{15} \mathrm{~N}$ and $\delta^{13} \mathrm{C}$ values were highly variable indicating there was some degree of inter-individual variability in the contribution of the OM sources available (Fig. 6). A portion of the ammocoetes sampled presented low $\delta^{13} \mathrm{C}$ values, suggesting the assimilation of ${ }^{13} \mathrm{C}$ - depleted sources such as aquatic and terrestrial vegetation (Fig. 6). Contrarily, other ammocoetes were more ${ }^{13} \mathrm{C}$ - enriched suggesting the consumption of MPB and SOM (Fig. 6). Moreover, several individuals presented $\delta^{15} \mathrm{~N}$ values much higher than the $\delta^{15} \mathrm{~N}$ values of the sources sampled by ca. 1 to $7 \%$ o suggesting that not all the available sources were sampled, or other factors may be responsible for those ${ }^{15} \mathrm{~N}$ - enriched values. The variability in the $\delta^{15} \mathrm{~N}$ and $\delta^{13} \mathrm{C}$ values and the fact that several ammocoetes presented $\delta^{15} \mathrm{~N}$ values outside the ranges of $\delta^{15} \mathrm{~N}$ values for the sources collected, suggest that the ammocoetes from site 3 were likely not fully equilibrated with the OM sources available at this site. For this reason, we did not conduct the mixing model analysis to those animals. 

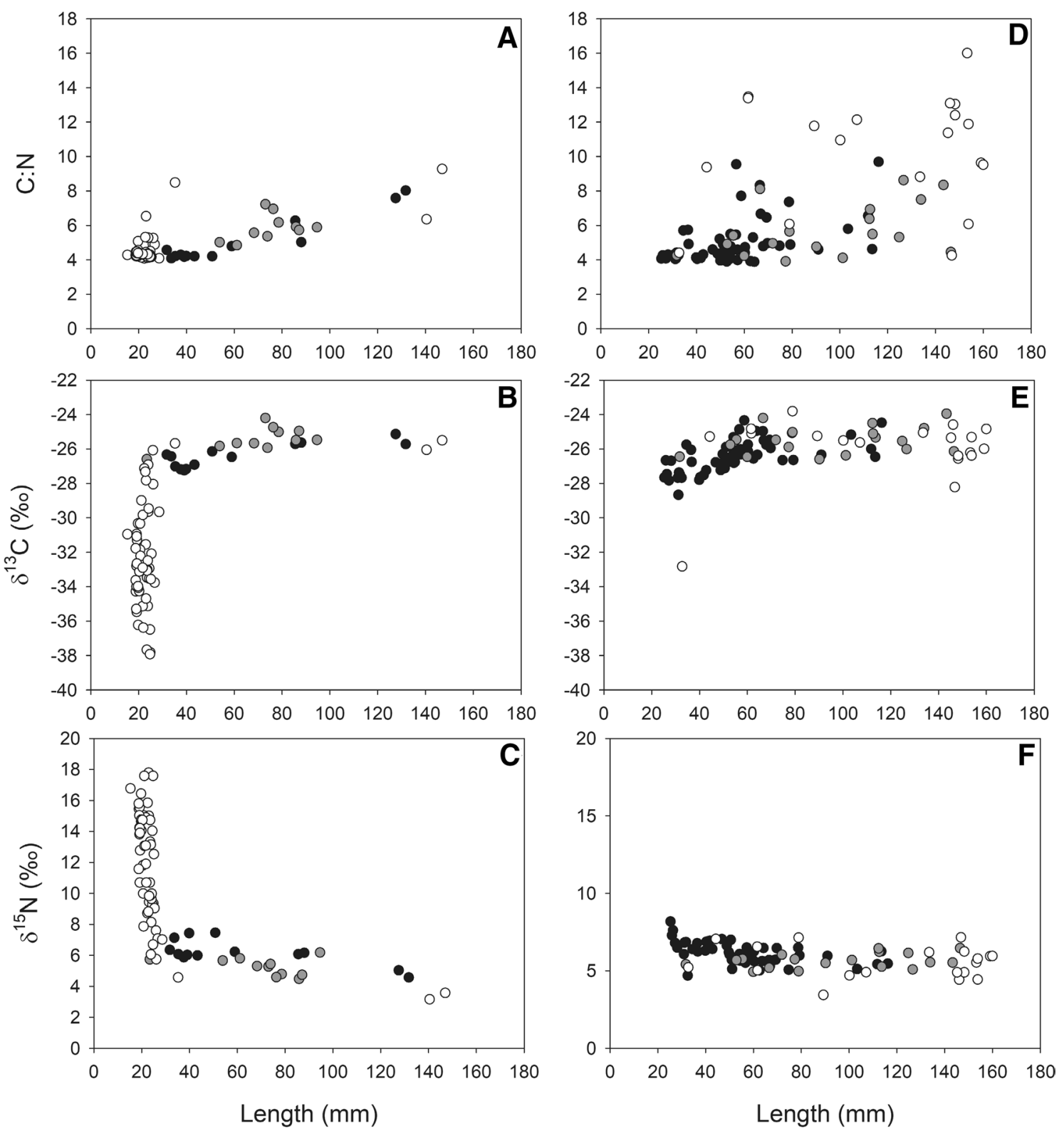

Fig. 4 Sea lamprey ammocoetes muscle tissue $\mathrm{C}: \mathrm{N}$ ratio $(\mathbf{a}, \mathbf{d}), \delta^{13} \mathrm{C}$ $(\% \circ ; \mathbf{b}, \mathbf{e})$, and $\delta^{15} \mathrm{~N}(\% \circ ; \mathbf{c}, \mathbf{f})$ as a function of animal length $(\mathrm{mm})$ collected at the end of the summer $2014(\mathbf{a}-\mathbf{c})$ and winter $2015(\mathbf{d}-\mathbf{f})$.

During winter, in all sampling sites, the stable isotope ratios of ammocoetes indicate they were using a mixture of ${ }^{15} \mathrm{~N}$ - depleted sources such as detritus and SOM, and ${ }^{13} \mathrm{C}$ enriched sources such as MPB (Fig. 6).

The stable isotope mixing model $(95 \% \mathrm{CI})$ indicate that terrestrial-derived OM (e.g. decaying and fresh plant detritus, POM) was the main contributor to the sea lamprey ammocoetes biomass. At the end of the summer, decaying detritus from riparian plants had a contribution (95\% CI) varying between $38-59 \%$ in site 1 and $55-73 \%$ in site 2 (Table 3).
Closed circles represent the ammocoetes collected at site 1, dark grey circles denote ammocoetes collected at site 2 , and open circles are those collected at site 3

At the end of the winter, there was an overall decrease in the relative contribution of decaying detritus to ammocoetes biomass and an increase in the contribution from fresh detritus from riparian plants (Fig. 6 and Table 3). The contribution of riparian plants varied between $37 \%$ and $54 \%$ in site 1 and between $13 \%$ and $40 \%$ in site 2 (Table 3). Microphytobenthos were also an important contribution to ammocoetes biomass, especially in site $2(20-35 \%)$ and site $3(41-72 \%)$ (Table 3). Sediment OM had a contribution varying between $26 \%$ and $46 \%$ in site $1,10-40 \%$ in site 2 , and $0-48 \%$ in site 3 . The POM was an important contributor only to the 


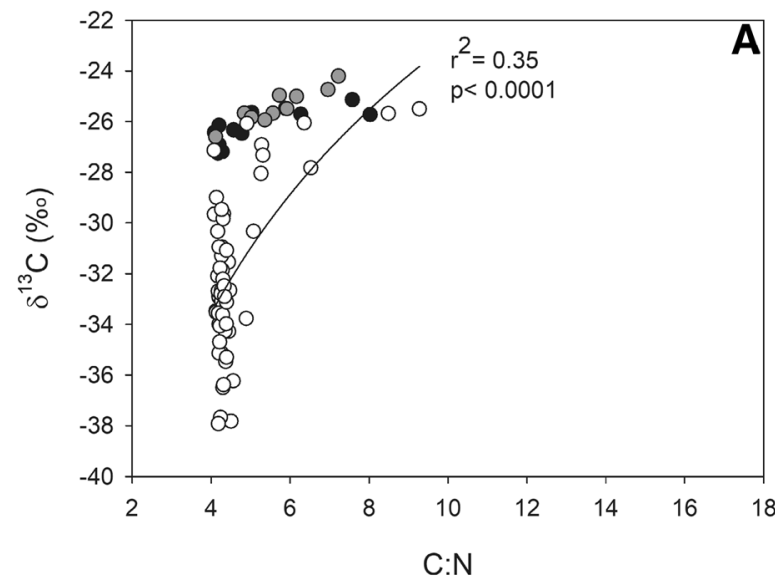

Fig. $5 \quad \delta^{13} \mathrm{C}$ and $\mathrm{C}: \mathrm{N}$ values of sea lamprey ammocoete muscle tissue collected at the end of the summer (a) and at the end of the winter (b). Closed circles represent the ammocoetes collected at site 1, dark

ammocoetes collected in site 2 , with a relative contribution varying between $5 \%$ and $35 \%$ (Table 3 ). The C: $\mathrm{N}_{\mathrm{POM}}$ was higher than 10 (29.4 \pm 17.7 -stations combined), suggesting that the POM was largely comprised of terrestrial-derived OM from upland or upriver (Hedges et al. 1986, 1997).

\section{Discussion}

Fresh and decaying detritus from the adjacent riparian vegetation were identified as the main food sources assimilated by sea lamprey ammocoetes throughout the study. In addition, $\mathrm{C}: \mathrm{N}$ values increased with length also towards the end of the winter, suggesting that sea lamprey ammocoetes may follow the all-or-none lipid accumulation strategy described by O'Boyle and Beamish (1977) to support its metamorphosis and recruitment into an adult animal.

\section{Variability in C:N and stable isotope ratios in sea lamprey ammocoetes}

Lipid content is an important factor controlling ammocoete metamorphosis (Moore and Potter 1976; Youson and Potter 1979), along with temperature and photoperiod (Manzon et al. 2015). In a study conducted on a landlocked population of sea lamprey, Lowe et al. (1973) found that larger $(>13 \mathrm{~cm})$ and metamorphosing ammocoetes presented higher lipid content than smaller individuals or those not in the metamorphosing stage, and that lipid content decreased towards the end of the metamorphosis. We did not measure the ammocoetes lipid content but it was shown that the C:N ratios of aquatic animals (including many fish species) are positively related with the lipid content (Post et al. 2007). Overall, the largest ammocoetes showed the highest C:N

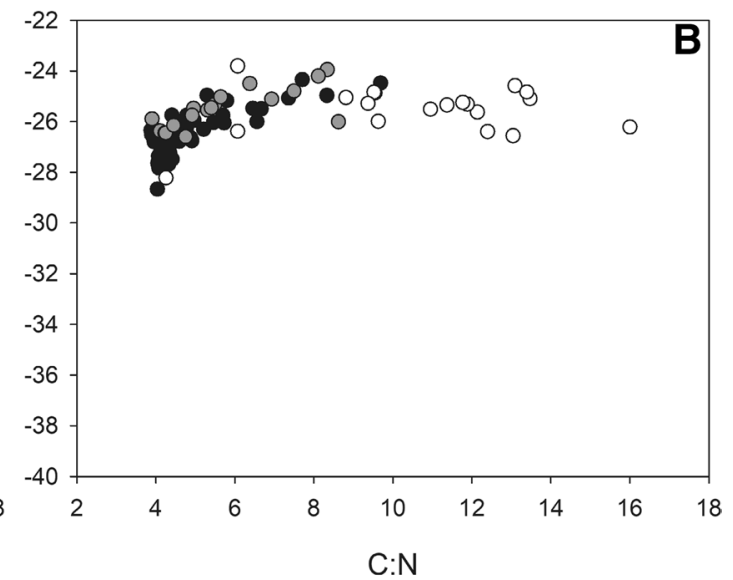

grey circles denote ammocoetes collected at site 2, and open circles are those collected at site 3

values, especially at the end of the winter. The metamorphosis in sea lampreys begins during the summer and is completed by the winter or early spring (Dawson et al. 2015). After the beginning of downstream migration, which in the Minho River basin usually occurs between November and January (unpublished data), the post-metamorphic larvae do not return to the nursery area. The largest ammocoetes collected at the end of the summer had C:N values up to $9(\mathrm{TL}=147 \mathrm{~mm})$, while at the end of the winter were as high as $16(\mathrm{TL}=153 \mathrm{~mm})$. This suggests that this population of sea lamprey may follow the all-or-none strategy, which states that lipids are maintained at low levels until an ammocoete approaches its maximum size, when it ceases growth and rapidly accumulates lipids (O'Boyle and Beamish 1977; Evans and Bauer 2016b). If the animal fails to reach a lipid threshold before the end of the growing season, it will maintain its lipid levels and attempt to increase it the following year (O'Boyle and Beamish 1977). Nonetheless, elevated $\mathrm{C}: \mathrm{N}$ values were not limited to the largest animals as ammocoetes may metamorphose over a wide range of sizes (Youson 1997).

Elevated C:N values (i.e. $>7$ ) were already observed in sea lamprey ammocoetes and Evans and Bauer (2016a) reported average $( \pm \mathrm{SD}) \mathrm{C}: \mathrm{N}$ values of $7.1 \pm 1.6(n=59)$ which are much lower than the ones found in this study for ammocoetes collected in site 3 at the end of the winter $(10.4 \pm 3.3, n=18)$. In fact, at the end of the winter, the ammocoetes with $\mathrm{C}: \mathrm{N}$ values higher than 7 had an average $( \pm \mathrm{SD})$ total length of $111 \pm 40 \mathrm{~mm}$, which likely corresponded to larvae 3 or more years old (Hardisty 1969; Potts et al. 2015), and were within the size range of transformers collected in the nearby Ulla River, Spain (Silva et al. 2013) and in Lake Ontario, Canada (Lowe et al. 1973). Future work is needed to confirm that $\mathrm{C}: \mathrm{N}$ values track lipid content in 

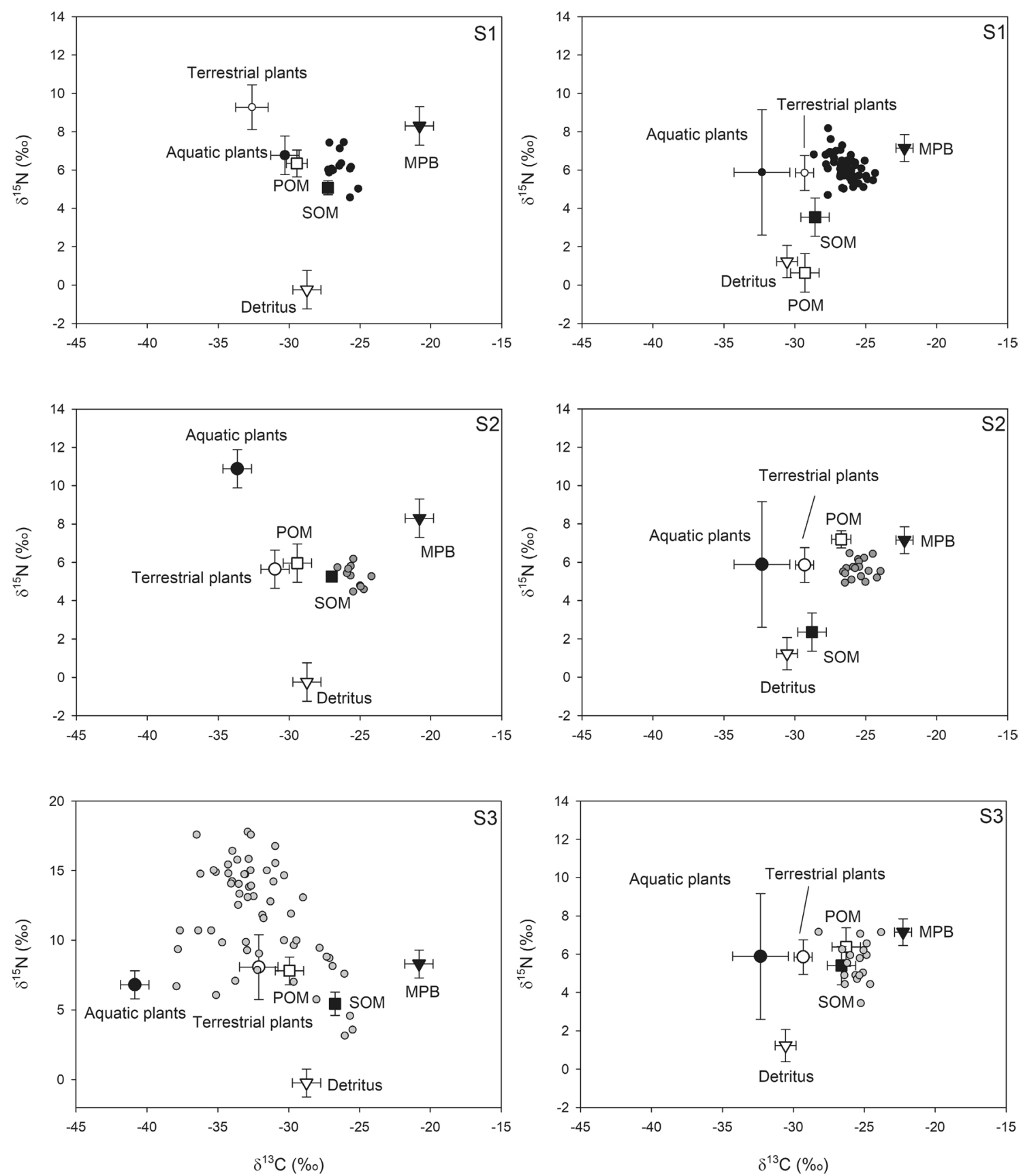

Fig. $6 \delta^{15} \mathrm{~N}$ and $\delta^{13} \mathrm{C}$ values (\%o) of ammocoetes collected in sites 1 (S1), 2 (S2), and 3 (S3) at the end of the summer 2014 (left panel) and winter 2015 (right panel). The potential sources for sea lamprey ammocoetes were aquatic plants (closed circles), terrestrial plants

(open circles), particulate organic matter (POM: open squares), sediment organic matter (SOM: closed squares), microphytobenthos (MPB: closed inverted triangle), and detritus (open inverted triangle). Note that the $\mathrm{y}$-axis scale is different in $\mathrm{S} 3$ at the end of the summer

ammocoetes, and that these values provide a good estimate for the different stages of ammocoetes development until they start to feed parasitically.

Overall, there was an increase in the $\delta^{13} \mathrm{C}$ values with length, which suggests that ammocoetes assimilated different sources/proportions of the same sources during growth. Although during this study it was possible to collect

individuals within a wide size range $(18.8-160 \mathrm{~mm})$, they were not equally distributed in space and time. Therefore, it was not possible to conduct a proper evaluation of the ontogenetic variability of the larval diet. Nonetheless, smaller individuals had lower $\delta^{13} \mathrm{C}$ values suggesting a greater reliance on ${ }^{13} \mathrm{C}$ - depleted sources such as fresh or decaying plant material. Larger ammocoetes presented 
Table 3 Proportion of each food source to ammocoetes biomass collected in sites 1 , and 2 at the end of the summer 2014 and in sites 1,2 , and 3 at the end of the winter 2015

\begin{tabular}{llllllll}
\hline Season & Site & Aq. plants & MPB & SOM & POM & Rip. plants & Detritus \\
\hline Summer & 1 & - & 16 & 35 & - & - & 47 \\
& 2 & - & $(7-26)$ & $(17-53)$ & & & $(38-59)$ \\
& & 28 & 2 & - & - & 65 \\
Winter & 1 & - & $(18-36)$ & $(0-21)$ & & & $(55-73)$ \\
& 2 & - & $(19-23)$ & $(25-46)$ & & 45 & - \\
& & & 28 & 26 & 21 & 26 & - \\
& 3 & - & $(20-35)$ & $(10-40)$ & $(5-35)$ & $(13-40)$ & \\
& & & 59 & 24 & - & - & 18 \\
& & & $(41-72)$ & $(0-48)$ & & & $(2-34)$ \\
\hline
\end{tabular}

Food sources included in the model were aquatic plants (Aq. plants), microphytobenthos (MPB), sediment organic matter (SOM), particulate organic matter (POM), riparian plants (Rip. plants), and detritus from riparian vegetation. The upper value indicates the most likely value (mode) and the ranges indicate the $95 \%$ Bayesian credibility intervals. Where no value is shown, sources were not included as end-members in the model higher $\delta^{13} \mathrm{C}$ values suggesting that ${ }^{13} \mathrm{C}$ - enriched sources such as MPB had a higher relative contribution to their biomass. In contrast with the $\delta^{13} \mathrm{C}$ values, the $\delta^{15} \mathrm{~N}$ values of ammocoetes tissue decreased with increasing size. Smaller larvae had high $\delta^{15} \mathrm{~N}$ values suggesting the assimilation of ${ }^{15} \mathrm{~N}$ - enriched $\mathrm{OM}$ such as fresh plant material while larger larvae assimilated ${ }^{15} \mathrm{~N}$-depleted material such as SOM and decaying plant material.

Ammocoetes collected in site 3 at the end of the summer, presented an unusual variability both for $\delta^{15} \mathrm{~N}$ and $\delta^{13} \mathrm{C}$ values, with values varying between $3.2 \%$ and $17.8 \%$ o for $\delta^{15} \mathrm{~N}$ and between $-38 \%$ and $-25.5 \%$ for $\delta^{13} \mathrm{C}$. This variability was not size dependent because the range of the total length from the ammocoetes showing this variability was low (18.8-30 mm). One possible explanation for this variability is related with organic pollution inputs. Usually, nitrate from human and animal wastes are typically more ${ }^{15} \mathrm{~N}$-enriched than other $\mathrm{N}$ sources, with $\delta^{15} \mathrm{~N}$ values ranging from 9\%o to 25\%o (Rolston et al. 1996; McKinney et al. 2002). However, if this organic pollution was local and prolonged in time, the ${ }^{15} \mathrm{~N}$ - enrichment would also be reflected in the aquatic producers, which was not the case. Moreover its effects would probably be observed in the downstream stations and also in the ammocoetes collected in site 3 at the end of the winter, after the rainy season, when the inputs from adjacent terrestrial ecosystems and upstream areas tend to increase (Dias et al. 2016). Therefore, we consider that for ammocoetes stable isotopes values to be influenced by organic pollution, those ammocoetes would need to come from other areas. The Veiga da Mira basin is highly forested nonetheless, upstream site 3 , there is an important area with agricultural and pasture activities, which could originate organic pollution inputs to the adjacent aquatic ecosystem.

Another factor that could be contributing to this variability is related with the ammocoetes dynamics. The ammocoetes collected in site 3 at the end of the summer were
YOY, because sea lamprey reproduction in the Minho River usually occurs between May and June (Sousa et al. 2012). It is hypothesized that after hatching, ammocoetes will disperse in order to find a suitable habitat to burrow (Derosier et al. 2007) and the inability to find suitable habitats will deplete the energy reserves and increase the time to first feeding (Kalmer 1992). Starving animals usually present elevated $\delta^{15} \mathrm{~N}$ values (Hobson et al. 1993) presumably because animals catabolize their own body proteins, producing isotopic enrichment analogous to that for ingested food (Gannes et al. 1997). This could explain the high $\delta^{15} \mathrm{~N}$ values found for some individuals in this site at the end of the summer. Thus, additional studies are needed in order to identify the causes for such variability in the $\delta^{15} \mathrm{~N}$ and $\delta^{13} \mathrm{C}$ values during early development.

\section{Sources of organic matter supporting sea lamprey ammocoetes production}

Sea lamprey ammocoetes assimilated different sources, including detritus and other terrestrial-derived OM, MPB, and SOM.

Terrestrial-derived OM was the most important contributor to sea lamprey ammocoetes biomass in the forms of plant biomass and its detritus, and terrestrial-derived POM (average C: $\mathrm{N}_{\text {POM }}$ ca. 30; Hedges et al. 1986, 1997). Previous studies based on gut content analysis showed that organic detritus was an important component of the diet of sea lamprey ammocoetes (Sutton and Bowen 1994). Detritus is usually considered low quality food item, but our study and others (Evans and Limburg 2015; Evans and Bauer 2016a) have shown that sea lamprey ammocoetes not only ingest terrestrial-derived OM, but also assimilate it. This is likely related to the influence of microbial transformation by heterotrophic prokaryotes and fungi which catalyze vascular plant-derived refractory substances into assimilable OM 
(Edwards and Meyer 1987). In fact, and unlike many other detritivorous fishes, ammocoetes lack specialized structures or physiological features able to digest detrital material (Sutton and Bowen 1994).

In streams with high aquatic productivity, the ammocoetes present higher growth rates, shorter times to metamorphosis and earlier juvenile downstream migration (Morkert et al. 1998; Weaver et al. 2018). Thus, the dependence on presumably less nutritious sources may slower growth rates and increase the time for ammocoetes development into juveniles. Nonetheless, ammocoetes appear to assimilate detritus efficiently due to long gut passage times and low metabolic rates (Sutton and Bowen 1994).

Although with this study we cannot conclude on the consequences of feeding on low quality food sources, we hypothesize that its consumption may be related with its availability in the ecosystem. The low $\mathrm{Chl} a$ concentrations (ca. $0.2 \mu \mathrm{g} \mathrm{L}^{-1}$ ) and the high C: $\mathrm{N}_{\text {POM }}$ values (average ca. 30) indicate that phytoplankton was not abundant during the period of the study and that POM was largely comprised of terrestrial-derived OM. Moreover, previous studies indicate that $\mathrm{Chl} a$ concentrations in the Minho River are overall low and close to the values obtained during this study (Brito et al. 2012; Dias et al. 2016) suggesting that phytoplankton productivity in this ecosystem may be limited.

Though plant derived material was the main food source for sea lamprey ammocoetes, SOM and MPB also contributed to their biomass. Overall there was an increase in the contribution of SOM towards the end of the winter while the relative contribution of MPB was similar throughout the study period.

One critical assumption for the food web reconstruction based on stable isotope analysis was that the fractionation values in ammocoetes are similar to those typically reported for aquatic organisms $\left(0.4 \% \circ \delta^{13} \mathrm{C},+3.4 \% \circ \delta^{15} \mathrm{~N}\right.$; Post 2002). Nonetheless, these average values may vary according to species, development stage or with the diet, among others (e.g. Vander Zanden and Rasmussen 2001; Caut et al. 2009). Recently, Evans and Bauer (2016a) suggested the use of low $\delta^{15} \mathrm{~N}$ average trophic fractionation values $(1.2 \pm 1.5 \%$ ) to identify the OM sources assimilated by sea lamprey ammocoetes, which were based on feeding experiments with captive larvae from the Pacific lamprey (Uh et al. 2014). If we had considered a lower $\mathrm{N}$ trophic fractionation, the relative importance of ${ }^{15} \mathrm{~N}$ - depleted sources such as detritus would decrease, while the relative importance of ${ }^{15} \mathrm{~N}$ - enriched sources such as fresh plant material or MPB would increase. However, this interpretation would not change our main result on the high relative importance of allochthonous subsidies to ammocoetes biomass.

Another critical step when conducting studies using stable isotopes is related with the lipid content. Because lipids are depleted in ${ }^{13} \mathrm{C}$, when compared to protein and carbohydrates, this usually results in an inverse relationship between C:N and $\delta^{13} \mathrm{C}$ (DeNiro and Epstein 1977). We did not correct for lipid content because a positive relationship between tissue $\delta^{13} \mathrm{C}$ and C:N was observed. If an arithmetic approach was used, that would result in an increase in the $\delta^{13} \mathrm{C}$ values in ca. $2 \%\left(\delta^{13} \mathrm{C}\right.$ up to $-18 \%$ ) and therefore in an increase on the relative contribution of autochthonous OM sources to the larger ammocoetes. Thus, further studies are needed not only to verify how $\mathrm{C}: \mathrm{N}$ track lipid content in sea lamprey ammocoetes but also to develop a specific arithmetic method to correct for lipid content.

In conclusion, our study shows that allochthonous OM from upriver and/or from the banks were the main contributors to ammocoetes biomass in Veiga da Mira River, with a similar contribution throughout the study period. The majority of detritus was identified as belonging to plants from riparian vegetation such as Alnus sp., Fraxinus sp., and Salix sp. Riparian ecosystems provide, regulate, and support important functions and services such as the stabilization of stream banks, mitigate stream flow, filter pollutants, nutrient cycling, regulate water temperature, among others (Naiman et al. 1993; Perry et al. 1999; Davies-Colley and Rutherford 2005; Kominoski et al. 2013). Riparian plants also provide food for several aquatic organisms from insects to fish (Pusey and Arthington 2003; England and Rosemond 2004). The fact that terrestrial-derived OM from the riparian corridors is a major source contributing to ammocoetes biomass throughout its development shows that there is a strong connectivity between the riverine food web and the adjacent riparian ecosystem. Thus, protection of both riparian and catchment forest cover are essential to preserve terrestrialaquatic linkages that are fundamental to maintain the stream food webs, which support the development of sea lamprey ammocoetes.

Acknowledgements We would like to thank the staff at Aquamuseu do Rio Minho for their collaboration during the fieldwork, to Rodrigo López for providing the map of the study area, and to Dr. Mark Kennard, Dr Stuart Findlay and two anonymous reviewers for their valuable comments and suggestions. This work was partially supported by the Strategic Funding UID/Multi/04423/2019 through national funds provided by Fundação para a Ciência e a Tecnologia (FCT, Portugal) and European Regional Development Fund (ERDF), in the framework of the programme PT 2020. All applicable international, national, and/or institutional guidelines for the care and use of animals were followed.

\section{References}

Almeida PR, Quintella BR, Dias NM, Andrade N (2002) The anadromous sea lamprey in Portugal: biology and conservation perspectives. In: International congress on the biology of fish: the biology of lampreys. American Fisheries Society, Physiology Section, Bethesda, Maryland, pp 49-58 
Anderson MJ, Gorley RN, Clarke KR (2008) PERMANOVA+ for PRIMER: guide to software and statistical methods. PRIMERE, Plymouth

Antunes C, Araújo MJ, Braga C, Roleira A, Carvalho R, Mota M (2011) Valorização dos recursos naturais da bacia hidrográfica do rio Minho. Final report from the project Natura Miño-Minho, Centro interdisciplinar de Investigação Marinha e Ambiental, Universidade do Porto

Araújo M, Silva S, Stratoudakis Y, Gonçalves M, Lopez R, Carneiro M, Martins R, Cobo F, Antunes C (2016) Sea lamprey fisheries in the Iberian Peninsula. In: Orlov A, Beamish R (eds) Jawless fishes of the world, vol 2. Cambridge Scholars Publishing, Cambridge, pp 115-148

Baxter CV, Fausch KD, Saunders WC (2005) Tangled webs: reciprocal flows of invertebrate prey link streams and riparian zones. Freshw Biol 50:201-220

Beamish FWH (1980) Biology of the North American anadromous sea lamprey, Petromyzon marinus. Can J Fish Aquat Sci 37:1906-1923

Brito AC, Brotas V, Caetano M, Coutinho TP, Bordalo AA, Icely J, Neto JM, Serôdio J, Moita T (2012) Defining phytoplankton class boundaries in Portuguese transitional waters: an evaluation of the ecological quality status according to the water framework directive. Ecol Indic 19:5-14

Canuel EA, Freeman EH, Wakeham SG (1997) Isotopic composition of lipid biomarker compounds in estuarine plants and surface sediments. Limnol Oceanogr 42:1570-1583

Caut S, Angulo E, Courchamp F (2009) Variation in discrimination factors $\left(\Delta^{15} \mathrm{~N}\right.$ and $\left.\Delta^{13} \mathrm{C}\right)$ : the effect of diet isotopic values and applications for diet reconstruction. J Appl Ecol 46:443-453

Clarke KR, Gorley RN (2006) PRIMER v6: user manual/tutorial. PRIMER-E, Plymouth

Cloern JE, Canuel EA, Harris D (2002) Stable carbon and nitrogen isotope composition of aquatic and terrestrial plants of the San Francisco Bay estuarine system. Limnol Oceanogr 47:713-729

Cole JJ, Carpenter SR, Kitchell J, Pace ML, Solomon CT, Weidel B (2011) Strong evidence of terrestrial support of zooplankton in small lakes based on stable isotopes of carbon, nitrogen, and hydrogen. Proc Natl Acad Sci USA 108:1975-1980

Collins SF, Baxter CV, Marcarelli AM, Wipfli MS (2016) Effects of experimentally added salmon subsidies on resident fishes via direct and indirect pathways. Ecosphere 7:e01248

Davies-Colley RJ, Rutherford JC (2005) Some approaches for measuring and modelling riparian shade. Ecol Eng 24(5):525-530

Dawson H, Quintella B, Almeida P, Treble A, Jolley J (2015) The ecology of larval and metamorphosing lampreys. In: Docker M (ed) Lampreys: biology, conservation and control. Fish \& fisheries Series, vol 37. Springer, Dordrecht, pp 75-137

DeNiro M, Epstein S (1977) Mechanism of carbon isotope fractionation associated with lipid synthesis. Science 197:261-263

Derosier AL, Jones ML, Scribner KT (2007) Dispersal of sea lamprey larvae during early life: relevance for recruitment dynamics. Environ Biol Fish 78:271-284

Dias E, Morais P, Cotter AM, Antunes C, Hoffman JC (2016) Estuarine consumers utilize marine, estuarine and terrestrial organic matter and provide connectivity among these food webs. Mar Ecol Prog Ser 554:21-34

Edwards RT, Meyer JL (1987) Bacteria as a food source for black fly larvae in a blackwater river. J N Am Benthol Soc 6:241-250

EIONET (2018) https://bd.eionet.europa.eu/activities/Natura_2000. Accessed 13 Dec 2018

England LE, Rosemond AD (2004) Small reductions in forest cover weaken terrestrial-aquatic linkages in headwater streams. Freshw Biol 49:721-734
Evans TM, Bauer JE (2016a) Identification of the nutritional resources of larval sea lamprey in two Great Lakes tributaries using stable isotopes. J Great Lakes Res 42:99-107

Evans TM, Bauer JE (2016b) Using stable isotopes and C: N ratios to examine the life-history strategies and nutritional sources of larval lampreys. J Fish Biol 88:638-654

Evans TM, Limburg KE (2015) The distribution of larval sea lampreys, Petromyzon marinus, and their nutritional sources in the Hudson River Basin. Northeast Nat 22:69-83

France RL (1995) Carbon-13 enrichment in benthic compared to planktonic algae: foodweb implications. Mar Ecol Prog Ser 124:307-312

Fry B, Sherr EB (1984) $\delta^{13} \mathrm{C}$ measurements as indicators of carbon flow in marine and freshwater ecosystems. Contrib Mar Sci 27:15-47

Gannes LZ, O'Brien DM, Del Rio CM (1997) Stable isotopes in animal ecology: assumptions, caveats, and a call for more laboratory experiments. Ecology 78:1271-1276

Gende SM, Edwards RT, Willson MF, Wipfli MS (2002) Pacific salmon in aquatic and terrestrial ecosystems: Pacific salmon subsidize freshwater and terrestrial ecosystems through several pathways, which generates unique management and conservation issues but also provides valuable research opportunities. Bioscience 52:917-928

Goericke R, Montoya JP, Fry B (1994) Physiology of isotopic fractionation in algae and cyanobacteria. In: Lajtha K, Michener RM (eds) Stable isotopes in ecology and environmental science. Blackwell Scientific, Oxford, pp 187-221

Hardisty MW (1969) Information on the growth of the ammocoete larva of the anadromous sea lamprey, Petromyzon marinus in British Rivers. J Zool Lond 158:139-144

Hedges JI, Clark WA, Quay PD, Richey JE, Devol AH, Santos UM (1986) Compositions and fluxes of particulate organic material in the Amazon River. Limnol Oceanogr 31:717-738

Hedges JI, Keil RG, Benner R (1997) What happens to terrestrial organic matter in the ocean? Org Geochem 27:195-212

Hobson KA, Alisauskas RT, Clark RG (1993) Stable-nitrogen isotope enrichment in avian tissues due to fasting and nutritional stress: implications for isotopic analyses of diet. Condor 95:388-394

Hocking MD, Reynolds JD (2011) Impacts of salmon on riparian plant diversity. Science 331:1609-1612

Hoffman JC, Bronk DA (2006) Interannual variation in stable carbon and nitrogen isotope biogeochemistry of the Mattaponi River, Virginia. Limnol Oceanogr 51:2319-2332

ICNF (2018) http://www2.icnf.pt/portal/pn/biodiversidade/rn2000/. Accessed 13 Dec 2018

Janetski DJ, Chaloner DT, Tiegs SD, Lamberti GA (2009) Pacific salmon effects on stream ecosystems: a quantitative synthesis. Oecologia 159:583-595

Kalmer E (1992) Early life history of fish: an energetics approach. Chapman and Hall, London

Kominoski JS, Shah JJF, Canhoto C, Fischer DG, Giling DP, González F, Griffiths NA, Larrañaga A, LeRoy CJ, Mineau MM, McElarney YR, Shirley SM, Swan SM, Tiegs SD (2013) Forecasting functional implications of global changes in riparian plant communities. Front Ecol Environ 11:423-432

Lajtha K, Marshall JD (1994) Sources of variation in the stable isotopic composition of plants. In: Lajtha K, Michener RM (eds) Stable isotopes in ecology and environmental science. Blackwell Scientific, Oxford, pp 1-21

Lorenzen CJ (1967) Determination of chlorophyll and pheopigments: spectrophotometric equations. Limnol Oceanogr 12:343-346

Lorrain A, Savoye N, Chauvaud L, Paulet Y-M, Naulet N (2003) Decarbonation and preservation method for the analysis of organic $\mathrm{C}$ and $\mathrm{N}$ contents and stable isotope ratios of low carbonated suspended particulate material. Anal Chim Acta 491:125-133 
Lowe DR, Beamish FWH, Potter IC (1973) Changes in the proximate body composition of the landlocked sea lamprey Petromyzon marinus (L.) during larval life and metamorphosis. J Fish Biol 5:673-682

Manzon RG, Youson JH, Holmes JA (2015) Lamprey metamorphosis. In: Docker MR (ed) Lampreys: biology, conservation and control. Springer, New York, pp 139-214

McKinney RA, Lake JL, Charpentier RA, Ryba S (2002) Using mussel isotope ratios to assess anthropogenic inputs to freshwater ecosystems. Environ Monit Assess 74:167-192

Moore JW, Potter IC (1976) Aspects of feeding and lipid deposition and utilization in the lampreys, Lampetra fluviatilis (L.) and Lampetra planeri (Bloch). J Anim Ecol 45:699-712

Morkert SB, Swink WD, Seelye JG (1998) Evidence for early metamorphosis of sea lampreys in the Chippewa River, Michigan. N Am J Fish Manag 18:966-971

Naiman RJ, Decamps H, Pollock M (1993) The role of riparian corridors in maintaining regional biodiversity. Ecol Appl 3:209-212

O'Boyle R, Beamish F (1977) Growth and intermediary metabolism of larval and metamorphosing stages of the landlocked sea lamprey, Petromyzon marinus L. Environ Biol Fishes 2:103-120

Parnell AC, Inger R, Bearhop S, Jackson AL (2010) Source partitioning using stable isotopes: coping with too much variation. PLoS One 5:e9672

Perry C, Vellidis G, Lowrance R, Thomas D (1999) Watershed-scale water quality impacts of riparian forest management. J Water Resour Plan Manag 125:117-125

Peterson BJ, Fry B (1987) Stable isotopes in ecosystem studies. Annu Rev Ecol Syst 18:293-320

Post DM (2002) Using stable isotopes to estimate trophic position: models, methods, and assumptions. Ecology 83:703-718

Post DM, Layman CA, Arrington DA, Takimoto G, Quattrochi J, Montaña CG (2007) Getting to the fat of the matter: models, methods and assumptions for dealing with lipids in stable isotope analyses. Oecologia 15:179-189

Potter IC (1980) Ecology of larval and metamorphosing lampreys. Can J Fish Aquat Sci 37:1641-1657

Potts DD, Dawson HA, Jones ML (2015) Validation of a relationship between statolith size and age of larval Great Lakes sea lamprey (Petromyzon marinus). Environ Biol Fish 98:1859-1869

Pusey BJ, Arthington AH (2003) Importance of the riparian zone to the conservation and management of freshwater fish: a review. Mar Freshw Res 54:1-16

Quintella BR (2000) Ecology of the sea lamprey (Petromyzon marinus L.) larval phase in the River Mondego. BSc Thesis, University of Lisbon, Portugal

Rex JF, Petticrew EL (2008) Delivery of marine-derived nutrients to streambeds by Pacific salmon. Nat Geosci 1:840-843

Richardson JS, Zhang Y, Marczak LB (2010) Resource subsidies across the land-freshwater interface and responses in recipient communities. River Res Appl 26:55-66

Rolston DE, Fogg GE, Decker DL, Louie DJ, Grimser ME (1996) Nitrogen isotope ratios identify nitrate contamination sources. Calif Agric 50:32-36

Silva S, Servia MJ, Vieira-Lanero R, Cobo F (2013) Downstream migration and hematophagous feeding of newly metamorphosed sea lampreys. Hydrobiologia 700:277-286
Smith BN, Epstein S (1970) Biogeochemistry of the stable isotopes of hydrogen and carbon in salt marsh biota. Plant Physiol 46:738-742

Smith BN, Epstein S (1971) Two categories of ${ }^{13} \mathrm{C} /{ }^{12} \mathrm{C}$ ratios for higher plants. Plant Physiol 47:380-384

Sousa R, Dias S, Antunes C (2007) Subtidal macrobenthic structure in the lower Lima estuary, NW of Iberian Peninsula. Ann Zool Fennici 44:303-313

Sousa R, Dias S, Guilhermino L, Antunes C (2008) Minho River tidal freshwater wetlands: threats to faunal biodiversity. Aquat Biol 3:237-250

Sousa R, Araújo MJ, Antunes C (2012) Habitat modifications by sea lampreys (Petromyzon marinus) during the spawning season: effects on sediments. J Appl Ichthyol 28:766-771

Stott AW, Davies E, Evershed RR, Tuross N (1997) Monitoring the routing of dietary and biosynthesised lipids through compoundspecific stable isotope $(\delta 13 \mathrm{C})$ measurements at natural abundance. Naturwissenschaften 84:82-86

Sutton TM, Bowen SH (1994) Significance of organic detritus in the diet of larval lampreys in the Great Lakes basin. Can J Fish Aquat Sci 51:2380-2387

Swink WD (2003) Host selection and lethality of attacks by sea lampreys (Petromyzon marinus) in laboratory studies. J Great Lakes Res 29:307-319

Uh CT, Jolley JC, Silver GS, Whitesel TA (2014) Larval Pacific lamprey feeding and growth in a captive environment. Annual report. US Fish and Wildlife Service, Columbia River Fisheries Program Office, Vancouver, WA

Vander Zanden MJ, Rasmussen JB (2001) Variation in $\delta^{15} \mathrm{~N}$ and $\delta^{13} \mathrm{C}$ trophic fractionation: implications for aquatic food web studies. Limnol Oceanogr 46:2061-2066

Wallace JB, Eggert SL, Meyer JL, Webster JR (1999) Effects of resource limitation on a detrital-based ecosystem. Ecol Monogr 69:409-442

Weaver DM, Coghlan SM, Zydlewski J (2016) Sea lamprey carcasses exert local and variable effects in a nutrient-limited Atlantic coastal stream. Can J Fish Aquat Sci 73:1616-1625

Weaver DM, Coghlan SM, Greig HS, Klemmer AJ, Perkins LB, Zydlewski J (2018) Subsidies from anadromous sea lamprey (Petromyzon marinus) carcasses function as a reciprocal nutrient exchange between marine and freshwaters. River Res Appl $34: 824-833$

Youson JH (1980) Morphology and physiology of lamprey metamorphosis. Can J Fish Aquat Sci 37:1687-1710

Youson JH (1997) Is Lamprey metamorphosis regulated by thyroid hormones? Amer Zool 37:441-460

Youson JH, Potter IC (1979) A description of the stages of metamorphosis in the anadromous sea lamprey, Petromyzon marinus L. Can J Zool 57:1808-1817

Publisher's Note Springer Nature remains neutral with regard to jurisdictional claims in published maps and institutional affiliations. 